\title{
Redescription of Parafilaria bovicola Tubangui, 1934 (Nematoda: Filarioidea) from Swedish Cattle
}

\author{
By L. M. Gibbons ${ }^{1}$, G. Zakrisson ${ }^{2}$, and A. Uggla ${ }^{2}$ \\ ${ }^{1}$ Department of Pathology and Infectious Diseases, The Royal Veterinary College, University of London, U. K., \\ and ${ }^{2}$ Department of Parasitology (SWEPAR), National Veterinary Institute and Swedish University of Agricul- \\ tural Sciences, Uppsala, Sweden.
}

\begin{abstract}
Gibbons LM, Zakrisson G, Uggla A: Redescription of Parafilaria bovicola Tubangui, 1934 (Nematoda: Filarioidea) from Swedish cattle. Acta vet. scand. 2000, 41, 85-91. - Parafilaria bovicola was introduced into Sweden and identified for the first time in Swedish cattle in 1978. Since then the parasite has become well established and has been responsible for substantial economic losses in Swedish beef production. Although studies have been undertaken on serodiagnosis, life cycle, vector and geographical distribution within Sweden this is the first full description of $P$. bovicola from Swedish cattle and the first study to use scanning electron microscopy. P. bulgarica Daskalov, 1944 is regarded as a synonym of $P$. bovicola Tubangui, 1934 . Tooth-like thickenings described on the anterior lobes of the oesophagus for the first time may assist the parasite in its migration through the host tissues.
\end{abstract}

Nematode parasite; morphology; Sweden.

\section{Introduction}

The bovine nematode parasite Parafilaria bovicola Tubangui, 1934 was reported for the first time in south-eastern Sweden by Nilsson (1978). The parasite, which is not indigenous to northern Europe, is believed to have been introduced by the movement of infected host animals, however, the exact source of the introduction is unknown. Lundquist (1983) undertook an extensive survey of the parasite which is now well established in Sweden where it utilizes Musca autumnalis, the face fly, as its vector (Bech-Nielsen et al. 1982). The adult worms migrate within the host causing damage to the subcutaneous and intramuscular tissues with subsequent eosinophilic infiltrations resulting in the so called "green meat" syndrome. The sexually mature females penetrate the skin causing haemorrhages. The parasite is therefore capable of causing substantial damage to beef production and, consequently, parafilariosis is a notifiable disease in Sweden.

Research on parafilariosis has included the development and application of serological diagnosis by ELISA (Sundquist et al. 1988, Sundquist et al. 1989), seasonal incidence and life cycle (Lundquist 1983) and studies on the vector M. autumnalis (Bech-Nielsen et al. 1982, Chirico 1994). Although the parasite has been known and studied in Sweden since 1978, this is the first morphological description of specimens from Swedish cattle, and the first description of the species using scanning electron microscopy.

\section{Materials and methods}

Specimens of Parafilaria bovicola were collected from the subcutaneous tissues of cattle at the abbatoir in Linköping, south-eastern Swe- 


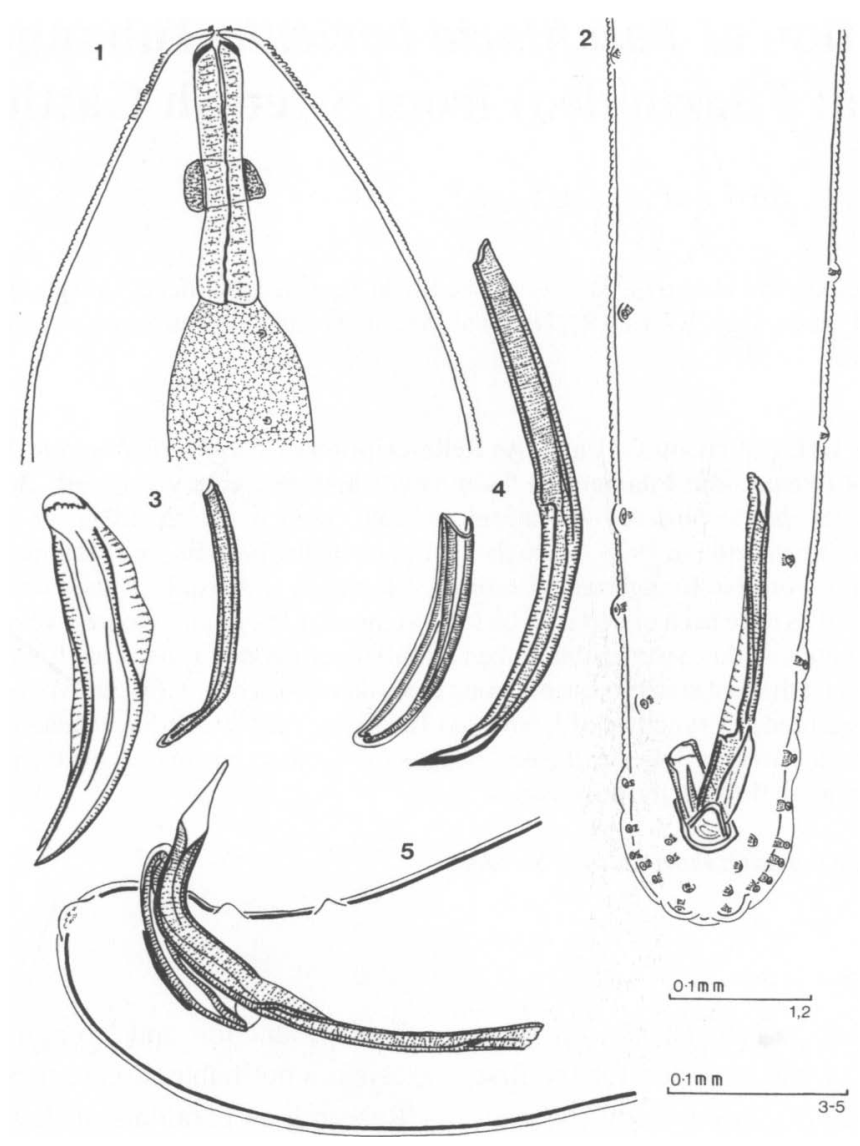

Figures 1-5. Parafilaria bovicola.

1. Anterior end of male. 2. Posterior end of male, ventral view. 3. Aberrant form of spicules.

4. Normal form of spicule. 5. Posterior end of male, lateral view.

den and sent to the Department of Parasitology, National Veterinary Institute, Uppsala for further study. The specimens were fixed in hot $70 \%$ ethanol.

Five male and 8 female specimens were cleared and examined in lactoglycerol (equal parts lactic acid, glycerol and distilled water). A single additional male specimen was stained in Horen's trichrome (Anonymous 1986) and cleared in lactophenol to examine the caudal papillae. An en face preparation of a female was made by mounting the specimen in glycerine jelly. Two male and 3 female specimens fixed in warm $70 \%$ alcohol were prepared for scanning electron microscopy using a standard dehydration series to ethanol. The specimens were dryed using the critical point drying technique with liquid carbon dioxide as the drying medium and coating the dried specimens with gold. 


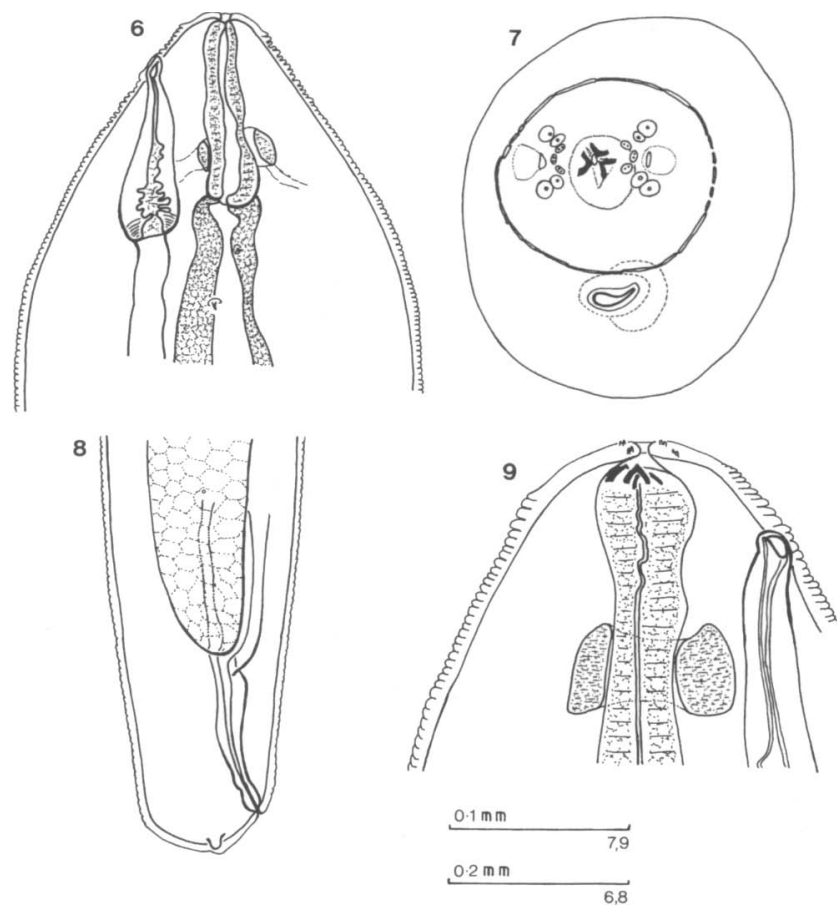

Figures 6-9. Parafilaria bovicola.

6. Anterior end of female. 7. Female, end-on view without cuticular striations. 8. Female tail, lateral view.

9. Higher magnification of anterior end of female showing details of buccal capsule and oesophagus.

\section{Redescription}

Parafilaria bovicola Tubangui, 1934 (Figs. 118)

\section{Taxonomic summary}

Definitive host: Bos taurus (domestic cattle)

Vector: Musca autumnalis, Muscidae

Specimens deposited: U.S. National Parasite Collection, Beltsville, Maryland, 20705-2350, U.S.A.; USPNC accession nos. 88141-88144.

\section{Diagnosis}

Male: Body 20-31 mm long, maximum width $0.31-0.36 \mathrm{~mm}$ at level of oesophagus; body tapers sharply anteriorly from widest part at level of oesophagus; cephalic region $0.064-0.08 \mathrm{~mm}$ wide, bluntly rounded, demarked by beginning of enlarged discontinous transverse striations which mark anterior part of body: 6 pairs of cephalic spines nearest mouth opening arranged in 2 lateral groups; 4 pairs of submedian cephalic papillae external to lateral groups of spines; pair of lateral amphids; excretory pore not observed; cervical papillae sharply pointed, project above body surface; nerve ring and cervical papillae 0.092-0.128 $\mathrm{mm}$ and 0.232-0.332 $\mathrm{mm}$ from the anterior end, respectively; buccal capsule poorly chitinised $0.008-0.016 \mathrm{~mm}$ long; each of 3 proximal lobes of oesophagus end in a chitinised thickening with a tooth-like projection; oesophagus $0.144-0.198 \mathrm{~mm}$ long, increasing in width slightly posteriorly, not di- 

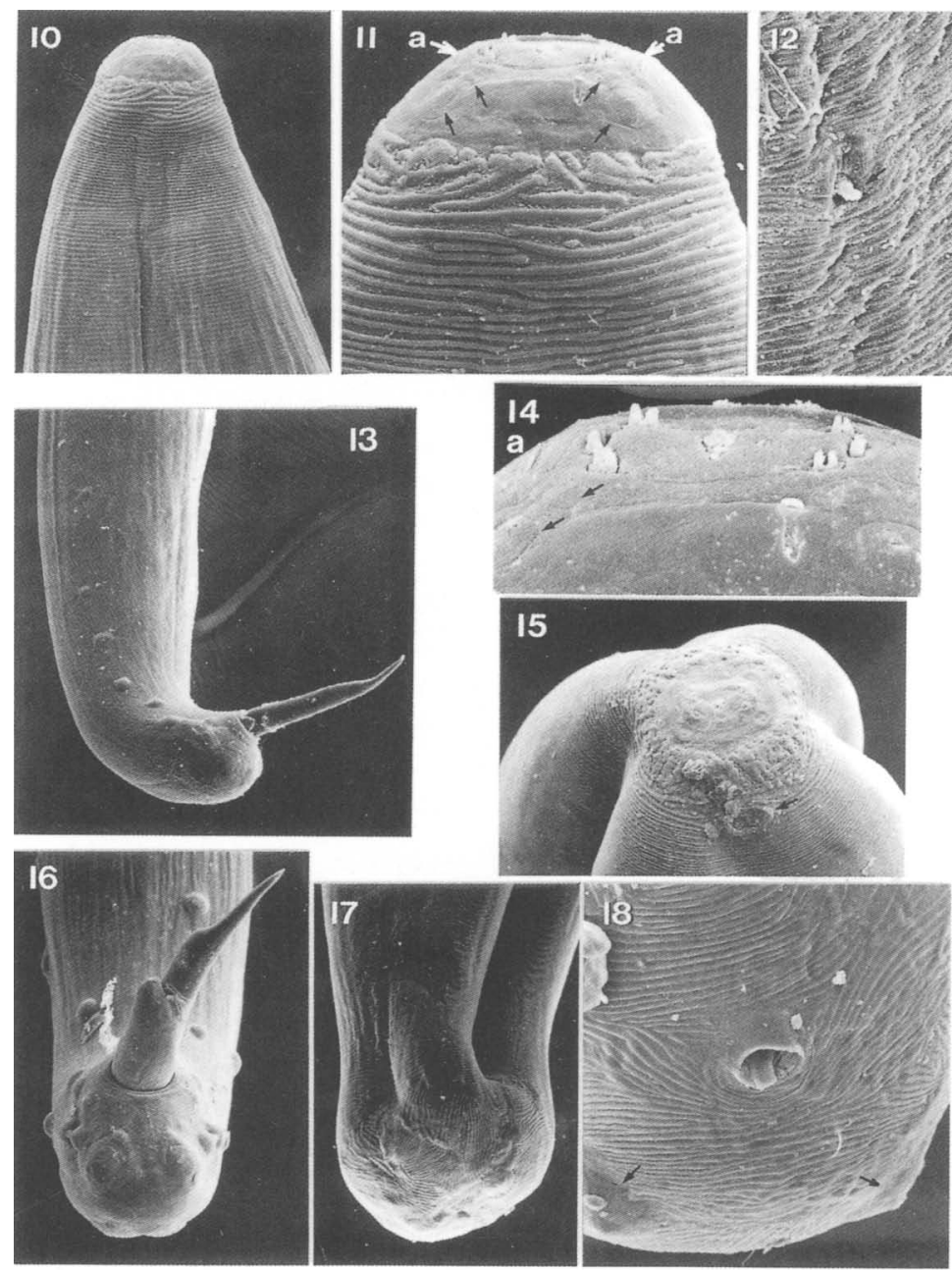

Scale bar

Figures 10-18. Parafilaria bovicola. Scanning electron micrographs.

10. Anterior end of male showing transverse striations.

11. Cephalic region of male showing sensory organs. $a=$ amphid; submedian cephalic papillae arrowed.

12. Male; one of cervical papilla arrowed.

13. Posterior end of male showing sensory papillae, lateral view.

14. Higher magnification of cephalic sensory organs of a male. $a=$ amphid; submedian cephalic papillae arrowed.

15. Anterior end of female showing position of vulva (arrowed).

16. Posterior end of male, ventral view.

17. Posterior end of female showing cuticular striations.

18. Higher magnification of posterior end of female showing anus and pair of papillae (arrowed).

Scale bar: 10) $75 \mu \mathrm{m}$; 11) $25 \mu \mathrm{m}$; 12) $18 \mu \mathrm{m}$; 13) $86 \mu \mathrm{m}$; 14) $12 \mu \mathrm{m}$; 15) $75 \mu \mathrm{m}$; 16) $50 \mu \mathrm{m}$; 17) $75 \mu \mathrm{m}$;

18) $25 \mu \mathrm{m}$. 
vided into muscular and glandular sections; 2 unequal and dissimilar spicules, left spicule $0.292-0.336 \mathrm{~mm}$ long with 2 distinct regions and a sharply pointed distal tip, right spicule $0.1-0.144 \mathrm{~mm}$ long with a bluntly pointed distal tip; gubernaculum $0.046-0.056 \mathrm{~mm}$ long; 1 specimen of the 8 males examined with aberrant spicules, left spicule $0.156 \mathrm{~mm}$ long with shortened distal half, right spicule $0.208 \mathrm{~mm}$ long and greater width than normal spicule; pedunculated sensory papillae on posterior end of male, 6 pairs of precloacal papillae asymmetrically arranged, postcloacal papillae arranged with 4 pairs lateral, 3 pairs ventral and 1 pair terminal; narrow lateral caudal alae present; tail bluntly rounded, 0.04-0.064 mm long.

Female: Body 41-52 mm long; maximum width $0.368-0.448 \mathrm{~mm}$ at level of oesophagus; body tapers sharply anteriorly from widest part at level of oesophagus; cephalic region 0.076$0.1 \mathrm{~mm}$, bluntly rounded, region demarked by beginning of enlarged discontinous transverse striations; cephalic sensory organs arranged as in male; excretory pore not observed; cervical papillae sharply pointed, project above body surface; nerve ring and cervical papillae 0.096$0.136 \mathrm{~mm}$ and $0.2-0.468 \mathrm{~mm}$ from anterior end, respectively; buccal capsule poorly chitinised, 0.008-0.02 mm long; each of 3 proximal lobes of oesophagus end in a chitinised thickening with a small tooth-like projection; oesophagus 0.184-0.226 $\mathrm{mm}$ long, increases in width slightly posteriorly, not divided into distinct muscular and glandular sections; vulva opens 0.04-0.072 $\mathrm{mm}$ from anterior end; ovejector $0.18-0.252 \mathrm{~mm}$ long with distal muscular sphincter separating it from the remainder of the uterus; uterus divides at $0.8 \mathrm{~mm}$ from vulvar opening; embroyonated eggs 0.02-0.032 $\mathrm{mm} \times 0.032-0.04 \mathrm{~mm}$, larvae present in uterus near ovejector in some specimens; ovoviviparous or viviparous; posterior end with distinct cuticular striations; reproductive tract extends to just anterior to end of intestine; distal end of alimentary canal and anus functional; tail 0.016-0.076 mm long with a pair of lateral, rounded papillae.

\section{Discussion}

The genus Parafilaria was erected by Yorke $\&$ Maplestone (1926) for P. multipapillosa (= Filaria multipapillosa Condamine and Drouilly, 1878, Filaria haemorrhagica, Railliet, 1885) from Equidae. It occurs in eastern and southern Europe, North Africa, Asia and South America (Soulsby 1965). Parafilaria bovicola Tubangui, 1934 was originally recorded from Bovidae in the Philippines and later from India (Patnaik \& Pande 1963) and different parts of Africa (Nevill 1975), Romania (Metianu 1949), Japan (Iida \& Taira 1994), France (Bussieras et al. 1987, Alzieu et al. 1993) and Sweden (Nilsson 1978). This species has also been recorded in imported cattle in Canada (Niilo 1968, Webster $\&$ Wilkins 1970) and more recently by Torgerson et al. (1998) in imported cattle in Ireland. However, it does not appear that $P$. bovicola has become established in the latter 2 countries as yet. Other species of the genus include $P$. bulgarica Daskalov, 1944 from cattle in Bulgaria, $P$. antipini Ruchliadev, 1947 from Cervidae in Europe and Asia (former USSR) and P. bassoni Ortlepp, 1962 from Antidorcas marsupialis and Syncerus caffer in Namibia and South Africa, respectively.

Tubangui (1934) descibed P. bovicola from female specimens only, recovered from skin nodules in cattle in the Philippines. He distinguised them from $P$. multipapillosa by the smaller size of the eggs, enclosed embryos and the appearance of the ornamentation of the cuticle on the anterior end of the body. Fain \& Herin (1950) described males and females of $P$. bovicola from cattle in the former Ruanda-Urundi (now Rwanda and Burundi) and Gibbons et al. (1994) presented a preliminary study of $P$. bo- 
vicola from Swedish cattle. The specimen described in the present study show measurements within the range described by Fain \& Herin (1950) but they have minor differences in the arrangement of the sensory papillae on the posterior end of the male.

Parafilaria bulgarica of Daskalov (1944) from cattle in Bulgaria does not appear to have been recorded in the litterature since its description. A comparison of the description of $P$. bulgarica with the specimens in the present study reveals a very close similarity in morphology between the 2 groups of specimens. Only minor differences in the arrangement of the sensory papillae on the posterior end of the male distinguish them from the desciption of $P$. bovicola by Fain \& Herin (1950). The specimens in this study are therefore assigned to $P$. bovicola, and P. bulgarica Daskalov, 1944 is regarded as a synonym of $P$. bovicola Tubangui, 1934.

The chitinised thickening forming a tooth-like projection on each of the 3 lobes of the oesophagus, described for the first time in the present study, may assist with the migration of the parasite through the host tissues. The aberrantly shaped spicules, observed in our material, have also been seen in other nematode groups (Drozdz 1965, Roy \& Beveridge 1997). Variability of spicule shape within a species may occur as a result of teratological changes, and some nematode species have previously been erroneously described as new on the basis of teratologically changed spicules, e.g. Ostertagia tatiani Puschmenkov, 1937 and O. petrovi Puschmenkov, 1937 (Drózdz 1965). However, spicule morphology is an important diagnostic character and the aberrant spicules descibed here are considered a deformation of the typical spicules of $P$. bovicola.

Parafilaria bovicola requires increased attention because of its economic importance for the cattle industry in endemic areas and its potential to effectively spread to new environments by the infected carriers. It is hoped that the morphological description here will aid the correct idenfication of the parasite in future studies and alert veterinarians to its ability to appear in new geographical locations.

\section{Acknowledgements}

The assistance of Dr. Hans Lundquist in providing material for this study is gratefully acknowledged. Dr. L. F. Khalil is acknowledged for constructive criticism of the manuscript. The scanning electron micrographs prepared by the senior author assisted by Mr. R. Tranfield are reproduced courtesy of CABI Biosciences.

\section{References}

Alzieu JP, Bourdeaux L, Ducos de Lahitte J, Schelcher F: La parafilariose bovine. (Bovine parafilariosis). Bull. G. T. V. 1993, 5, 85-94.

Anonymous: Manual of veterinary parasitological laboratory techniques. Ministry of Agriculture, Fisheries and Food, Reference Book 418. Her Majesty's Stationery Office, London, 1986, 160 pp.

Bech-Nielsen S, Bornstein S, Christensson D, Wallgren T-B, Zakrisson G, Chirico J: Parafilaria bovicola (Tubangui, 1934) in cattle: Epizootiology, vector studies and experimental transmission of Parafilaria bovicola to cattle. Am. J. vet. Res. 1982, 43, 948-954.

Bussieras J, Chermette R, Gresset M, Mas M: Nouvelles observations sur les plaies d'ete des bovins de l'est de la France. (New observations on the summer sores of bovines in the east of France). Rev. Med. vet. 1987, 163, 853-859.

Chirico J: Prehibernating Musca autumnalis (Diptera: Muscidae): an overwintering host for parasitic nematodes. Vet. Parasitol. 1994, 52, 279284.

Daskalov P: Beitag zur Erforschung der Rinderparafialriose. (Contribution to the research on parafilariosis in cattle. Zeitschr. Parasitenkd. 1944, 13, 254-264.

$\operatorname{Dróz} d z J$ : Studies on helminths and helminthiases in Cervidae I. Revision of the subfamily Ostertagiinae Sarwar, 1956 and an attempt to explain the phylogenesis of its representatives. Acta parasitol. polon. 1965, 13, 445-481.

Fain A, Herin V: Parafilaria bovicola Tubangui (1934) au Ruanda-Urundi, description du male. 
(Description of the male Parafilaria bovicola Tubangui (1934) in Ruanda-Urundi. Ann. Parasitol. hum. comp. 1950, 25, 167-177.

Gibbons LM, Zakrisson G, Uggla A: Parafilaria (Nematoda, Filariidae), the cause of "green meat" in Swedish cattle. Abstracts Volume II, VIII Internat. Congr. Parasitol., Izmir, Turkey, 10-14 October, 1994, 309.

Iida $M$, Taira $N$ : Two cases of parafilariasis in dairy cattle and treatment of hemorrhage with levamisole topical application. J. vet. med. Sci. 1994, 56, 203-205.

Lundquist H: Parafilaria bovicola (Tubangui, 1934) established in Swedish cattle. Nord. Vet.-Med. 1983, 35, 57-68.

Metianu T: Considérations sur la parafilariose hemorragique des bovins. Parafilaria bovicola en Roumanie. (Report on haemorrhagic parafilariosis of bovines. Parafilaria bovicola in Rumania). Ann. Parasitol. hum. comp. 1949, 24, 54-59.

Nevill EM: Preliminary report on the transmission of Parafilaria bovicola in South Africa. Onderstepoort J. vet. Res. 1975, 42, 41-48.

Niilo L: Bovine hemorrhagic filariasis in cattle imported into Canada. Can. vet. J. 1968, 9, 132-137.

Nilsson NG: Parafilaria bovicola - rapport från en arbetsgrupp. (Parafilaria bovicola - report from a working group). Sv. Vet.tidn. 1978, 30, 785-787.

Ortlepp RJ: Parafilaria bassoni spec. nov. from the eyes of springbuck (Antidorcas marsupialis). Onderstepoort J. vet. Res. 1962, 29, 165-168.

Roy EA, Beveridge I: Abnormal spicule development in a laboratory strain of Trichostrongylus vitrinus. J. Helminthol. 1997, 71, 359-361.

Ruchliadev DP: (A new filaria from the hypodermic tissue of Crimean deer; in Russian). DAN S.S.S.R. 1947, 55, 565-567.

Soulsby EJL: Textbook of Veterinary Clinical Parasitology Volume I. Helminths. Blackwell Scientific Publications, Oxford, U. K., 1965, 1120 pp.

Sundquist B, Bech-Nielsen S, Zakrisson G: Characterization and purification of Parafilaria bovicola antigens by chromatofocusing to enhance specificity in serodiagnosis. Vet. Parasitol. 1989, 33, 309-318.

Sundquist B, Zakrisson G, Bech-Nielsen S, Bianco $A E$ : Preparation and evaluation of the specificity of Parafilaria bovicola antigen for detection of specific antibodies by ELISA. Vet. Parasitol. 1988, 28, 223-235.

Torgerson PR, Doherty L, Healy AM: Bovine haemorrhagic parafilariosis in an imported Charolais bull. Irish vet. J. 1998, 51, 27-29.

Tubangui MS: Nematodes in the collection of the Philippine Bureau of Science, II: Filariodea. Philipp. J. Sci. 1934, 55, 115-122.

Webster WA, Wilkins DB: The recovery of Parafilaria bovicola Tubangui, 1934 from an imported Charolais bull. Can. vet. J. 1970, 11, 13-14.

Yorke $W$, Maplestone PA: The nematodes of vertebrates. J. A. Churchill, London, U. K. 1926, xi + $536 \mathrm{pp}$.

\section{Sammanfattning}

Beskrivning av Parafilaria bovicola Tubangui, 1934 (Nematoda: Filarioidea) från svenska nötkreatur.

Parafilaria bovicola är en filarid nematod vars förekomst hos nötkreatur beskrevs i Sverige första gången 1978. Sedan dess har parasiten etablerat sig $\mathrm{i}$ landet och orsakar fortfarande förluster inom nötköttsproduktionen. I Sverige har studier bl.a. gjorts över parasitens epidemiologi i landet samt utvecklingen av serologisk diagnostik för påvisande av infektionen, men föreliggande arbete är den första fullständiga morfologiska beskrivningen av $P$. bovicola från svenska nötkreatur och den första studien som utnyttjar svepelektronmikroskopi. P. bulgarica Daskalov, 1944 föreslås vara en synonym till $P$. bovicola Tubangui, 1934. De tandlika förtjockningar på de främre loberna av esofagus som beskrivs här för första gången kan ha som funktion att underlätta parasitens migration genom värddjurets vävnader.

(Received July 20, 1999; accepted December 7, 1999).

Reprints may be obtained from: A. Uggla, Department of Parasitology, National Veterinary Institute, SE-751 89 Uppsala, Sweden. E-mail: arvid.uggla@sva.se, tel: +46186740 00, fax: +4618 309162. 